Original Research Paper

\title{
Dynamics of Buses - Part II
}

\author{
${ }^{1}$ Relly Victoria Virgil Petrescu, ${ }^{2}$ Raffaella Aversa, ${ }^{1}$ Gheorghe Frăţilă, \\ ${ }^{3}$ Taher M. Abu-Lebdeh, ${ }^{2}$ Antonio Apicella and ${ }^{1}$ Florian Ion Tiberiu Petrescu
}

${ }^{I}$ ARoTMM-IFToMM, Bucharest Polytechnic University, Bucharest, (CE), Romania

${ }^{2}$ Department of Architecture and Industrial Design, Advanced Material Lab,

Second University of Naples, 81031 Aversa (CE), Italy

${ }^{3}$ North Carolina A and T State University, USA

Article history

Received: 02-03-2018

Revised: 02-04-2018

Accepted: 20-04-2018

Corresponding Author:

Florian Ion Tiberiu Petrescu

ARoTMM-IFToMM, Bucharest

Polytechnic University,

Bucharest, (CE), Romania

Email: scipub02@gmail.com

\begin{abstract}
Dynamics, or dynamic processes, is the part of mechanics dealing with the study of processes trying to describe as real as possible the movement of a body, element, mechanism, car, etc., also taking into account the action of the forces on the respective system with their influence on the actual movement of system. The present paper aims to present the study of the dynamics of the vehicles, with particularization on the buses. Here are the main elements of the bus dynamics, taking into account all the elements that influence the dynamic operation of a bus, in general and in particular situations, with emphasis on the main systems and elements that act on the actual, dynamic, on a normal path or on an inclined with an alpha angle path.
\end{abstract}

Keywords: Mechanisms, Machines, Buses, Dynamics, Kinematics

\section{Introduction}

Transport is the movement of persons as well as goods, signals or information from one place to another. The term comes from Latin, from "transport", trans (over) and porting (meaning wearing or carrying).

Transport is an activity that arose with the existence of man. The physical limits of the human body in terms of walking distances and the quantity of goods that could be transported led, over time, to the discovery of a variety of ways and means of transport.

Transport facilitates access to natural resources and stimulates trade.

The transport sector has different aspects. Simplifying and generalizing can be discussed by three major branches: Infrastructure, vehicles, management:

Transport infrastructure, including the entire transport network (streets, motorways, railways, waterways, flight color, pipelines, etc.) and terminals (airports, railway stations, bus stations, etc.).

Vehicles of all types: Motor vehicles, trains, ships, airplanes, etc., together with all aspects related to vehicle design, construction, diagnosis and exploitation, road traffic, management.

Transport management is the responsibility of transport engineering and engineering for the design of transport networks and systems, aiming at optimizing transport systems, increasing transport safety, protecting the environment, etc.

Land transport is the most widespread form of transport. People can move by their own forces or using means of transport that use human power, such as a bicycle, or they can use animal traction to pull wagons or other types of carriages. The most widespread and efficient form of land transport uses vehicles equipped with liquid-fueled engines (Frățilă et al., 2011; Pelecudi, 1967; Antonescu, 2000; Comănescu et al., 2010; Aversa et al., 2016a; 2016b; 2016c; 2016d; 2017a; 2017b; 2017c; 2017d; 2017e; Berto et al., 2016a; 2016b; 2016c; 2016d; Mirsayar et al., 2017; Cao et al., 2013; Dong et al., 2013; De Melo et al., 2012; Garcia et al., 2007; GarciaMurillo et al., 2013; He et al., 2013; Lee, 2013; Lin et al., 2013; Liu et al., 2013; Padula and Perdereau, 2013; Perumaal and Jawahar, 2013; Petrescu and Petrescu, 1995a; 1995b; 1997a; 1997b; 1997c; 2000a; 2000b; 2002a; 2002b; 2003; 2005a; 2005b; 2005c; 2005d; 2005e, 2016a; 2016b; 2016c; 2016d; 2016e; 2013; 2012a; 2012b; 2011; Petrescu et al., 2009; 2016a; 2016b; 2016c; 2016d; 2016e; 2017a; 2017b; 2017c; 2017d; 2017e; 2017f; $2017 \mathrm{~g} ; 2017 \mathrm{~h} ; 2017 \mathrm{i} ; 2017 \mathrm{j} ; 2017 \mathrm{k} ; 2017 \mathrm{l} ; 2017 \mathrm{~m}$; 2017n; 2017o; 2017p; 2017q; 2017r; 2017s; 2017t; 2017u; 2017v; 2017w; 2017x; 2017y; 2017z; 2017aa; 2017ab; 2017ac; 2017ad; 2017ae; Petrescu and Calautit, 2016a; 2016b; Reddy et al., 2012; Tabaković et al., 2013;
Science

Publications
C 2018 Relly Victoria Virgil Petrescu, Raffaella Aversa, Gheorghe Frăţilă, Taher M. Abu-Lebdeh, Antonio Apicella and Florian Ion Tiberiu Petrescu. This open access article is distributed under a Creative Commons Attribution (CC-BY) 3.0 
Tang et al., 2013; Tong et al., 2013; Wang et al., 2013; Wen et al., 2012; Antonescu and Petrescu, 1985; 1989; Antonescu et al., 1985a; 1985b; 1986; 1987; 1988; 1994; 1997; 2000a; 2000b; 2001).

\section{Materials and Methods}

\section{Airflow Resistance}

Air resistance is the force that opposes the forwarding of the bus while moving into the air.

The causes of air resistance when driving a bus are as follows:

1. Pressure exerted by the air particles encountered on the front of the bus

2. Friction of the outer surface of the bodywork by air particles

3. In particular, whirlwinds are produced in front of the bus and a depression zone (Fig. 1) is created behind the bus, which consumes much energy (generating high resistances on the bus)

For the calculation of air resistance, the motion of the bodies is used in fluid media at speeds below $300 \mathrm{~m} / \mathrm{s}$. In this case, the air resistance is given by the relation (1), in which: $c$ is a coefficient of resistance to advance which depends on the shape of the body; $\rho$ air density in $\mathrm{kg} / \mathrm{m}^{3}$; $A$ is the transverse (frontal) area of the bus in $m^{2} ; v$ is the bus speed in $\mathrm{m} / \mathrm{s}$.

$$
R_{a}=c \cdot \rho \cdot A \cdot v^{2}
$$

If we take into account that the air density $\rho$ has very small (insignificant) variations at the height from the ground at which the vehicles circulate, then the product c. $\rho=K=$ constant and the relation (1) takes the form (2) bears the name of the aerodynamic coefficient:

$$
R_{a}=K \cdot A \cdot v^{2}
$$

Taking into account that for buses their travel speed $\mathrm{v}$ is usually expressed in $\mathrm{km} / \mathrm{h}$, the relation (2) can be written in the form (3), where $V$ is the speed of the bus in $\mathrm{km} / \mathrm{h}$ :

$R_{a}=K \cdot A \cdot\left(\frac{V}{3,6}\right)^{2}=\frac{1}{13} K \cdot A \cdot V^{2}$

The power consumed by the bus $[W]$ to overcome the air resistance will be given by the relationship (4), where as previously mentioned the bus speed $V$ is introduced in $\mathrm{km} / \mathrm{h}$, the cross-sectional area of the bus $A$ is given in $m^{2}$ and the power consumed $\mathrm{Pa}$ results in $W$ :

$P_{a}=R_{a} \cdot v=\frac{1}{13} K \cdot A \cdot V^{2} \cdot \frac{V}{3,6}$
$=\frac{1}{13} K \cdot A \cdot V^{2} \cdot 0,27 \cdot V=0,021 K \cdot A \cdot V^{3}$

For a driver to be able to operate economically on the bus, he should go as low as possible, given that the treadmill is the main factor that increases the air resistance when the bus goes and even the third; in other words, the air resistance increases directly in proportion to the cube of the bus speed. Obviously a bus on a national or international road can not travel at very low speed and then the only way to reduce the air resistance when driving a bus is to reduce constructively the aerodynamic coefficient $K$ from the body design.

For rapid, approximate, good results, the surface $A$ can easily be determined by the relationship (5), where $B$ is the bus path (front gauge, distance between the front axle wheels) and $H$ the maximum bus height, both measured in $m$.

Instead of gauge or track, the width of the bus (trolley, or truck, as the case may be) may be more accurate (Fig. 2):

$A=B \cdot H$

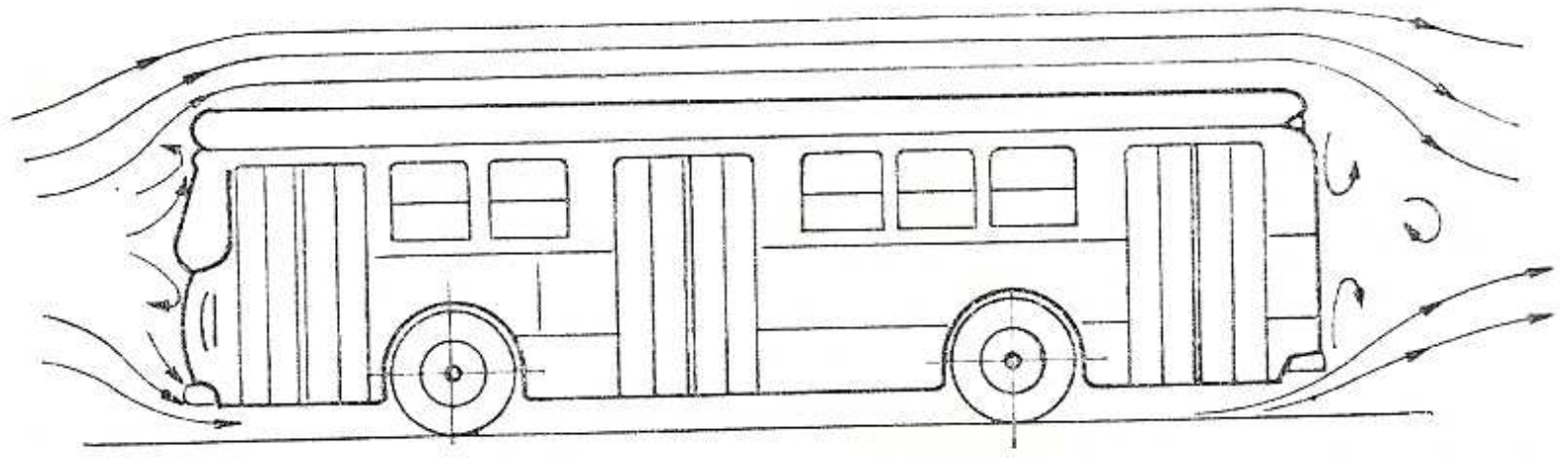

Fig. 1: Spectrum of leakages produced by air lines on a bus on the road 


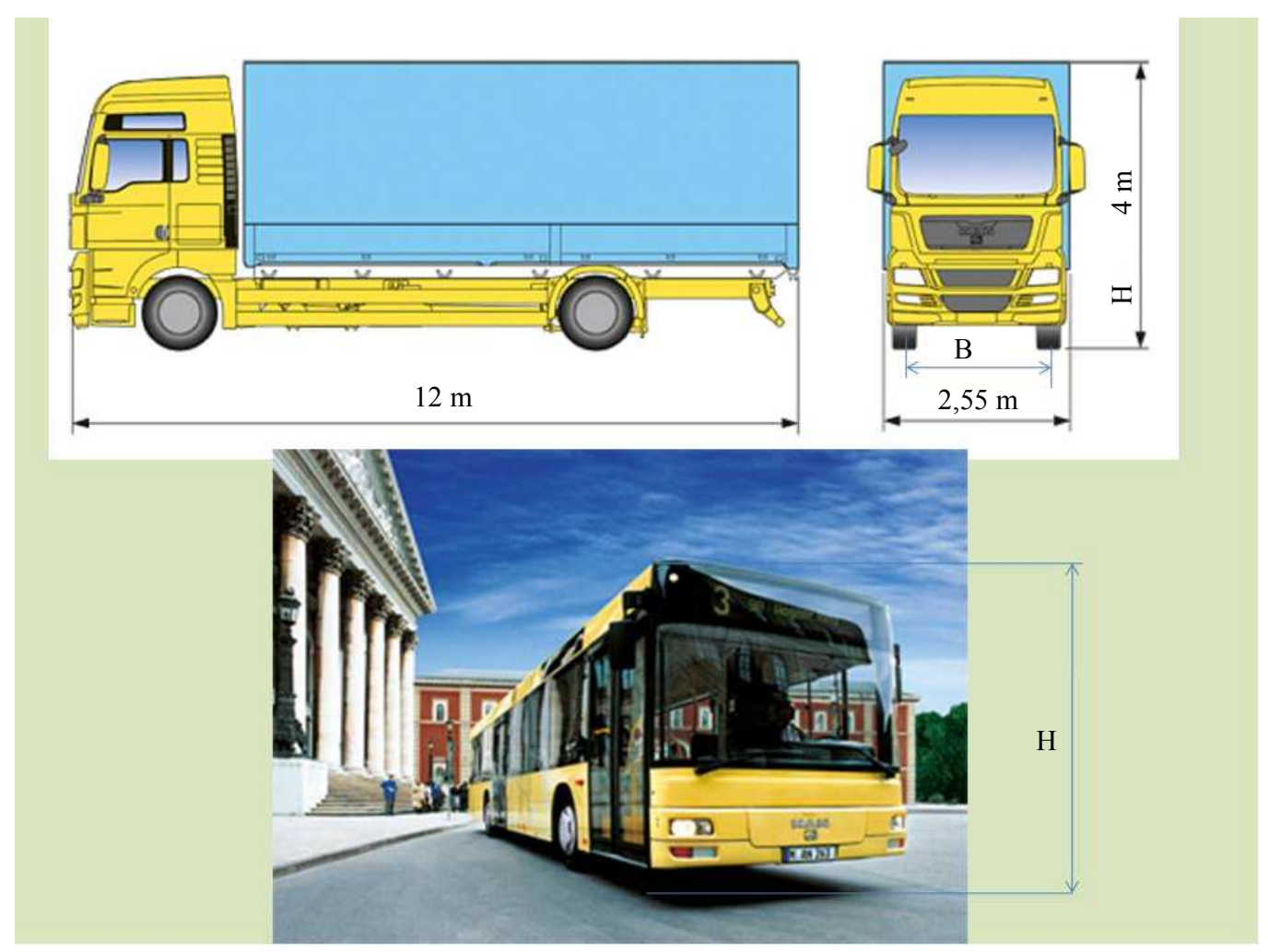

Fig. 2: Schema for approximate front surface calculation

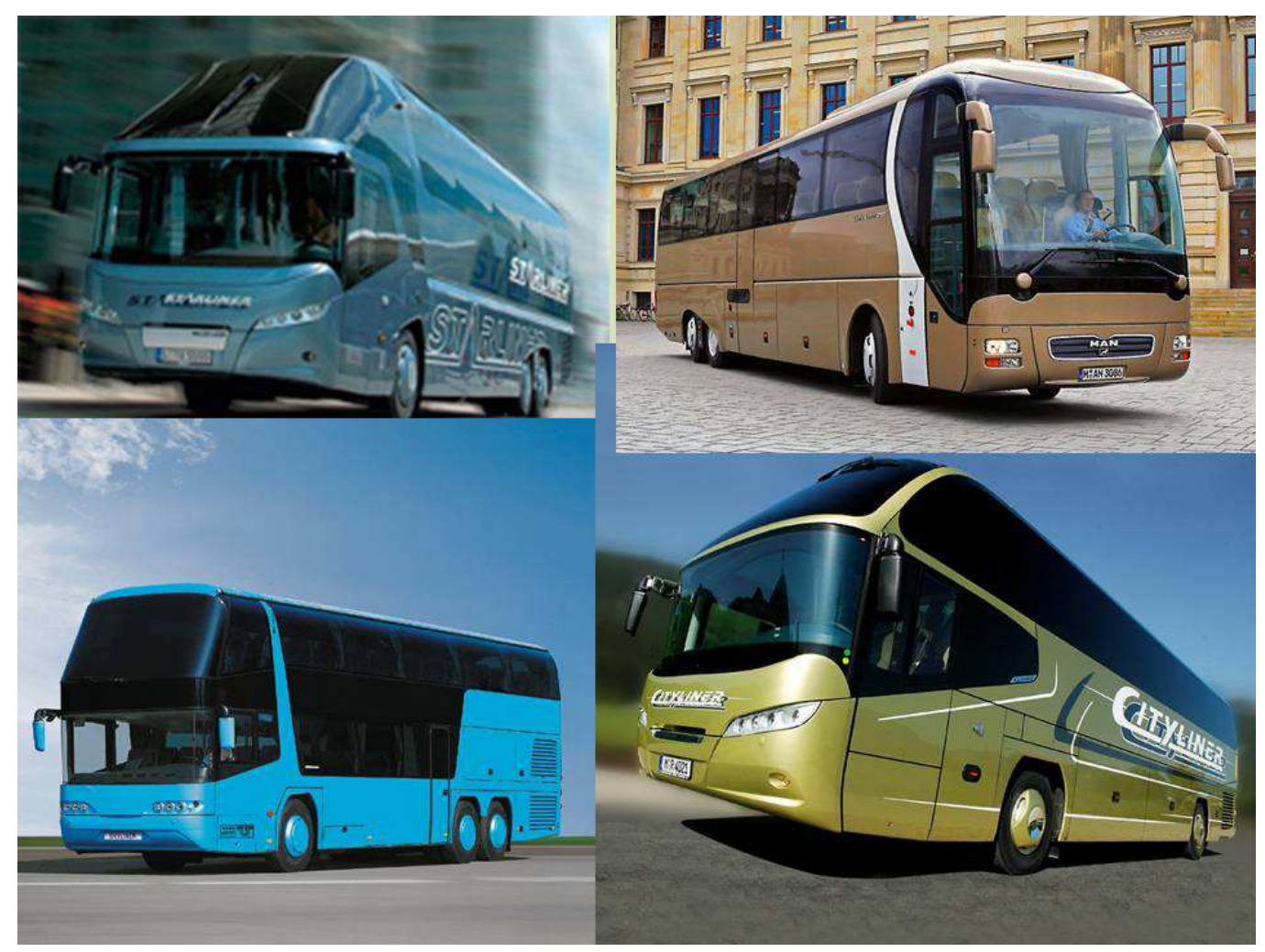

Fig. 3: New building designs for buses to reduce aerodynamic coefficients 


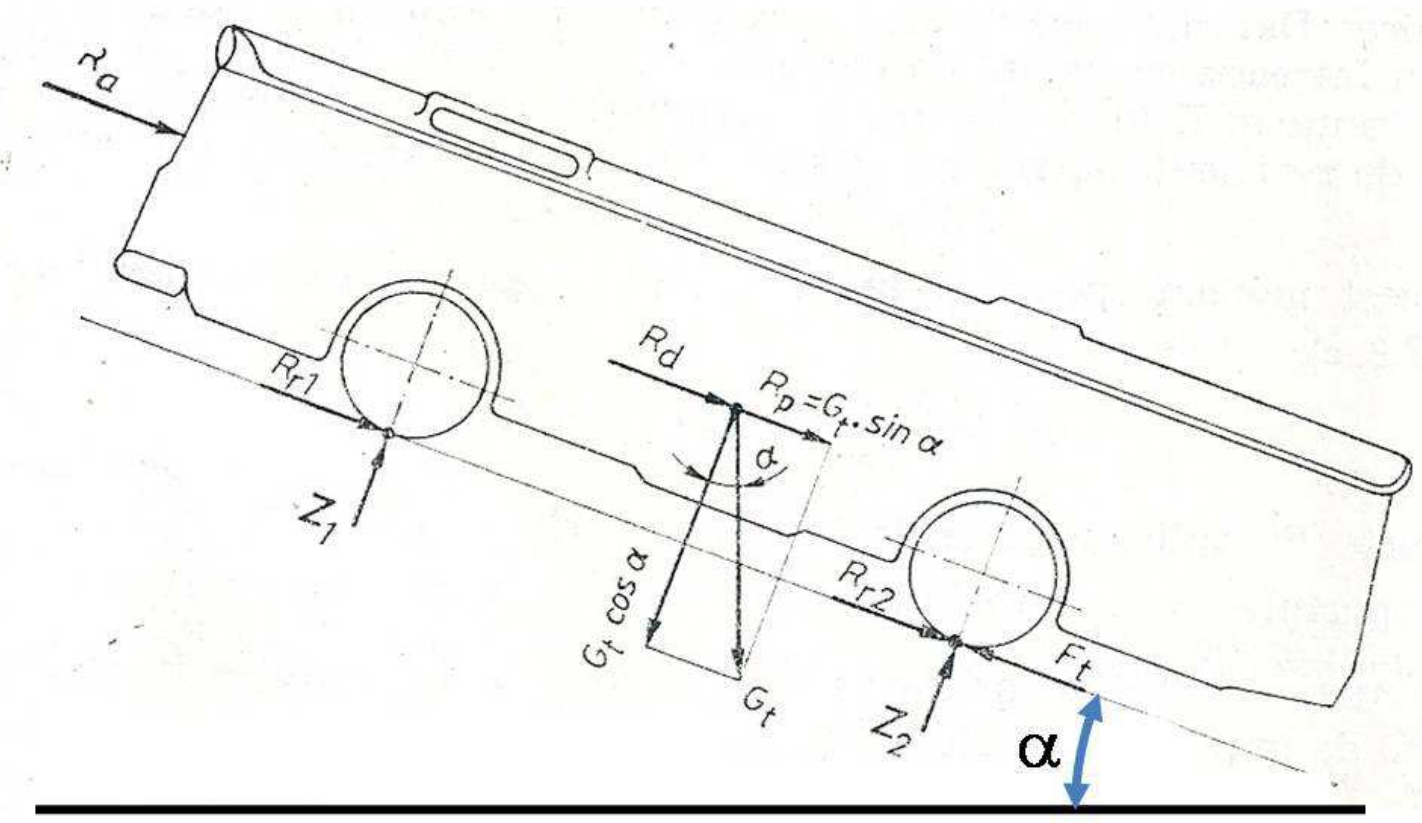

Fig. 4: Resistance to climbing a slop of a bus

For urban buses (including trolleybuses) the aerodynamic coefficient $K=0,030 \ldots 0,044$, while the frontal area of a bus varies within $A=4,5 \ldots 12,5 \mathrm{~m}^{2}$ for the usual cases.

As shown, it is necessary to reduce the aerodynamic coefficient from the design, which is why modern buses have new constructive shapes (Fig. 3).

\section{Resistance to Climbing a Slope}

The slope resistance of a bus (Fig. 4) is a component parallel to the sloping path (of the slope) of the total weight of the bus $G_{t}$, i.e., the component $R_{p}=G_{t} \cdot \sin \alpha$, given by the relation (6):

$$
R_{p}=G_{t} \cdot \sin \alpha
$$

where, $G_{t}$ is the total weight of the bus given in daN, the angle $\alpha$ represents the slope angle of the slope versus the horizontal in degrees deg.

In the case of small slopes $\left(\alpha<10^{\circ}\right)$ we can approximate: $\sin \alpha=\operatorname{tg} \alpha=\alpha$ [rad] $=p$. Thus the resistance to the ascension of a slope will be given by the relation (7):

$$
R_{p}=G_{t} \cdot p
$$

When descending a slope, the weight component of the bus becomes an active force, tending to increase its speed.

The power consumed by an extra bus for ascending an angle slope $\alpha$, precisely for overcoming the slope resistance, is given by the relation (8):

$$
\left\{\begin{array}{l}
P_{p}[W]=R_{p}[N] \cdot v[\mathrm{~m} / \mathrm{s}] \\
=R_{p}[N] \cdot 0,27 \cdot V[\mathrm{~km} / \mathrm{h}] \\
=10 \cdot R_{p}[\mathrm{daN}] \cdot 0,27 \cdot V[\mathrm{~km} / \mathrm{h}] \\
=R_{p}[\mathrm{daN}] \cdot 2,7 \cdot V[\mathrm{~km} / \mathrm{h}] \\
=G_{t}[\mathrm{daN}] \cdot \sin \alpha \cdot 2,7 \cdot V[\mathrm{~km} / \mathrm{h}] \\
=G_{t}[\text { daN] } \cdot p \cdot 2,7 \cdot V[\mathrm{~km} / \mathrm{h}]
\end{array}\right.
$$

\section{Resistance to Acceleration}

Acceleration resistance is a force that opposes the bus movement, which occurs at the speed of the bus and the start of it, being an inertial force. Force acceleration force is the force of inertia that opposes speed variations and is given by the relation (9), where $\mathrm{g}$ is the gravitational acceleration in $\mathrm{m} / \mathrm{s}^{2}$, considered constant (for a given location of the planet and a certain height on average with the calculation value of 9.81 $\mathrm{ms}^{-2}$ ), a is the acceleration of the bus which creates the inertia force, given also in $\mathrm{m} / \mathrm{s}^{2}$ and $G_{t}$ is the total weight of the bus, which in the international system of measurement is taken in $\mathrm{N}$, technically given in daN, the force $\mathrm{Rd}$ having the same unit of measure as the weight of the $G_{t}$ bus. If $G_{t}$ is considered in daN obviously and $\mathrm{Rd}$ will result all in daN:

$R_{d}=m \cdot a=\frac{G_{t}}{g} \cdot a$

In relation (9), the additional movements of certain assemblies belonging to the bus, such as the engine's 
flywheel, transmission organs, which also perform rotational movements with some influence on the final translation movement of the bus, the lost power and on its stability.

For rotation of the organs during the acceleration period, additional power is spent so that the acceleration resistance will actually be composed of the inertia force corresponding to the accelerated translation of the entire bus and the inertia force corresponding to the angular acceleration of the movement of the organs in rotation. This second force of inertia can be taken into account in calculations by means of a coefficient $\delta$, called coefficient for increasing the speeds of the masses in rotation. The total resistance to bus acceleration will now be given more precisely by the relationship (10):

$$
R_{d}=\delta \cdot m \cdot a=\delta \cdot \frac{G_{t}}{g} \cdot a
$$

The value of the coefficient $\delta$ is determined by calculation. It can be determined by an empirical relationship (11), where icv is the transmission ratio of the gearbox in that gear and $\sigma$ is a coefficient, which for buses takes values in the beach: $\sigma=0,05 \ldots 0.07$ :

$$
\delta=1+\sigma \cdot i_{c v}^{2}
$$

The power required to overcome the bus acceleration resistance can be calculated using the relationship (12):

$$
\left\{\begin{array}{l}
P_{d}[W]=R_{d}[N] \cdot v[\mathrm{~m} / \mathrm{s}] \\
=\delta \cdot \frac{G_{t}[N]}{g} \cdot a \cdot v[\mathrm{~m} / \mathrm{s}] \\
=\delta \cdot \frac{10 \cdot G_{t}[d a N]}{g} \cdot a \cdot 0,27 \cdot V[\mathrm{~km} / \mathrm{h}] \\
=\delta \cdot \frac{G_{t}[d a N]}{g} \cdot a \cdot 2,7 \cdot V[\mathrm{~km} / \mathrm{h}]
\end{array}\right.
$$

\section{Results and Discussion}

\section{Normal Pathway Reactions at Bus Decks}

Determination of normal reactions on decks is considered to be a bus that ascends a slope $\alpha$ with an accelerated motion. The forces and moments acting on the bus are shown in Fig. 5.

Writing the equation of moments to the center of gravity of the bus, the relation (13) is obtained, in which: $Z_{1}$ and $Z_{2}$ are the normal dynamic reactions at the front and rear axles; $G_{t}$ is the total weight of the bus that decomposes on the inclined slope of the slope in the two components $G_{t} \cdot \sin \alpha$ parallel to the path and $G_{t} \cdot \cos \alpha$ perpendicular to the track; $R_{a}$ is the air resistance on the bus; $R_{d}$ is the acceleration resistance of the bus; $M_{r u l 1}$ and
$M_{r u / 2}$ are the moments corresponding to rolling resistance for the front axle and rear axle respectively; $F_{t}$ is the traction force at the engine wheels; $h_{g}$ is the height of the center of gravity of the bus and $h_{a}$ is the height of the center of pressure where air resistance is assumed to act; $r_{r}$ is the radius of the wheels:

$$
\begin{aligned}
& Z_{1} \cdot a-Z_{2} \cdot b+M_{r u l 1}+M_{r u l 2} \\
& +F_{t} \cdot h_{g}+R_{a} \cdot\left(h_{a}-h_{g}\right)=0
\end{aligned}
$$

For the determination of the two reactions, the equation of projection of the forces on a plane perpendicular to the plane of the tread (14) is also written:

$$
Z_{1}+Z_{2}=G_{t} \cdot \cos \alpha
$$

Taking into account the relation (15), the relation (13) takes the form (16):

$$
\begin{aligned}
& M_{r u l 1}+M_{r u l 2}=f \cdot r_{r} \cdot Z_{1}+f \cdot r_{r} \cdot Z_{2} \\
& =f \cdot r_{r} \cdot\left(Z_{1}+Z_{2}\right)=f \cdot r_{r} \cdot G_{t} \cdot \cos \alpha \\
& Z_{1} \cdot a-Z_{2} \cdot b+f \cdot r_{r} \cdot G_{t} \cdot \cos \alpha \\
& +F_{t} \cdot h_{g}+R_{a} \cdot\left(h_{a}-h_{g}\right)=0
\end{aligned}
$$

Since in most buses the ha-hg difference is very small, the product $R_{a}\left(h_{a}-h_{g}\right)$ can be neglected, so that the relation (16) obtains the approximate, simplified form, (17):

$Z_{1} \cdot a-Z_{2} \cdot b+f \cdot r_{r} \cdot G_{t} \cdot \cos \alpha+F_{t} \cdot h_{g}=0$

Thus, a two-equation system (18) with two unknowns, $Z_{1}, Z_{2}$, is obtained, from which two dynamic normal reactions at the bus bridges, $Z_{1}$ and $Z_{2}$ (system $19)$, where $L=a+b$ :

$\left\{\begin{array}{l}Z_{1} \cdot a-Z_{2} \cdot b+f \cdot r_{r} \cdot G_{t} \cdot \cos \alpha+F_{t} \cdot h_{g}=0 \\ Z_{1}+Z_{2}=G_{t} \cdot \cos \alpha\end{array}\right.$

$\left\{\begin{array}{l}Z_{1}=\frac{G_{t} \cdot\left(b-f \cdot r_{r}\right) \cdot \cos \alpha-F_{t} \cdot h_{g}}{L} \\ Z_{2}=\frac{G_{t} \cdot\left(a+f \cdot r_{r}\right) \cdot \cos \alpha+F_{t} \cdot h_{g}}{L}\end{array}\right.$

Taking into account that the product $f . r_{r}$ has a small value in relation to the distances (lengths) $a, b$, the system (19) gets the simplified form (20):

$\left\{\begin{array}{l}Z_{1}=\frac{G_{t} \cdot b \cdot \cos \alpha-F_{t} \cdot h_{g}}{L} \\ Z_{2}=\frac{G_{t} \cdot a \cdot \cos \alpha+F_{t} \cdot h_{g}}{L}\end{array}\right.$ 


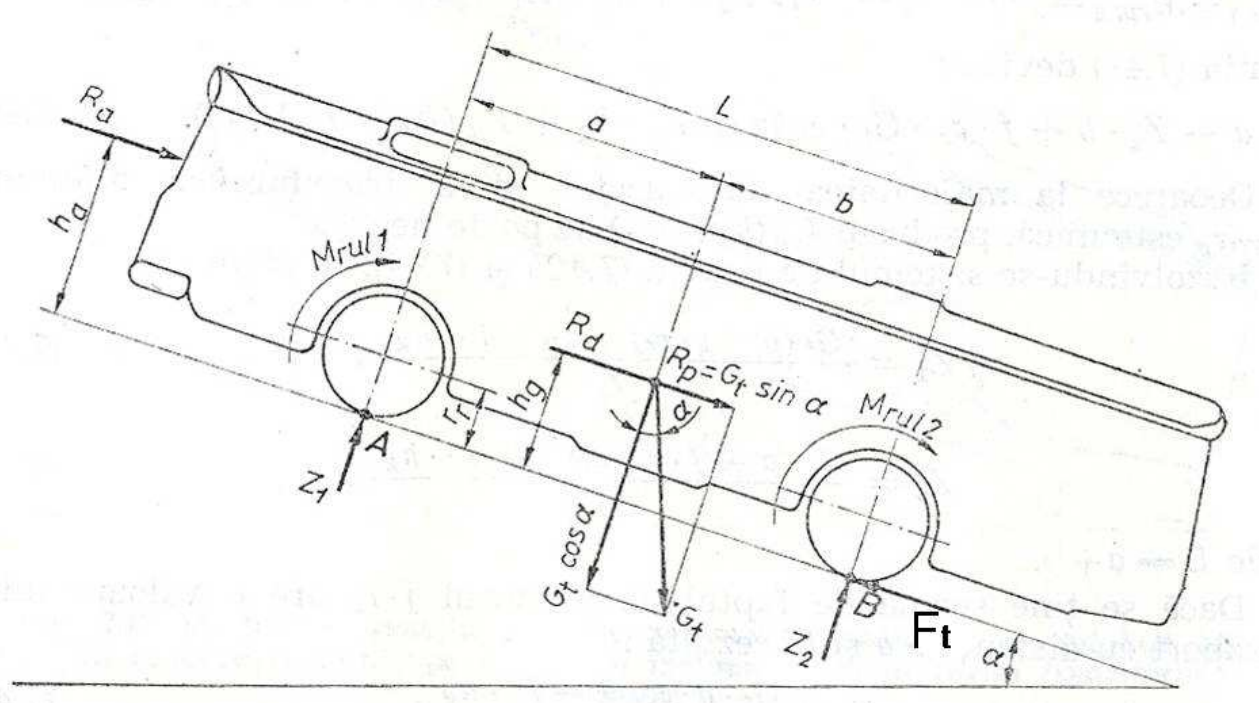

Fig. 5: The forces, moments and reactions that act on a bus when climbing a slope with an accelerated motion

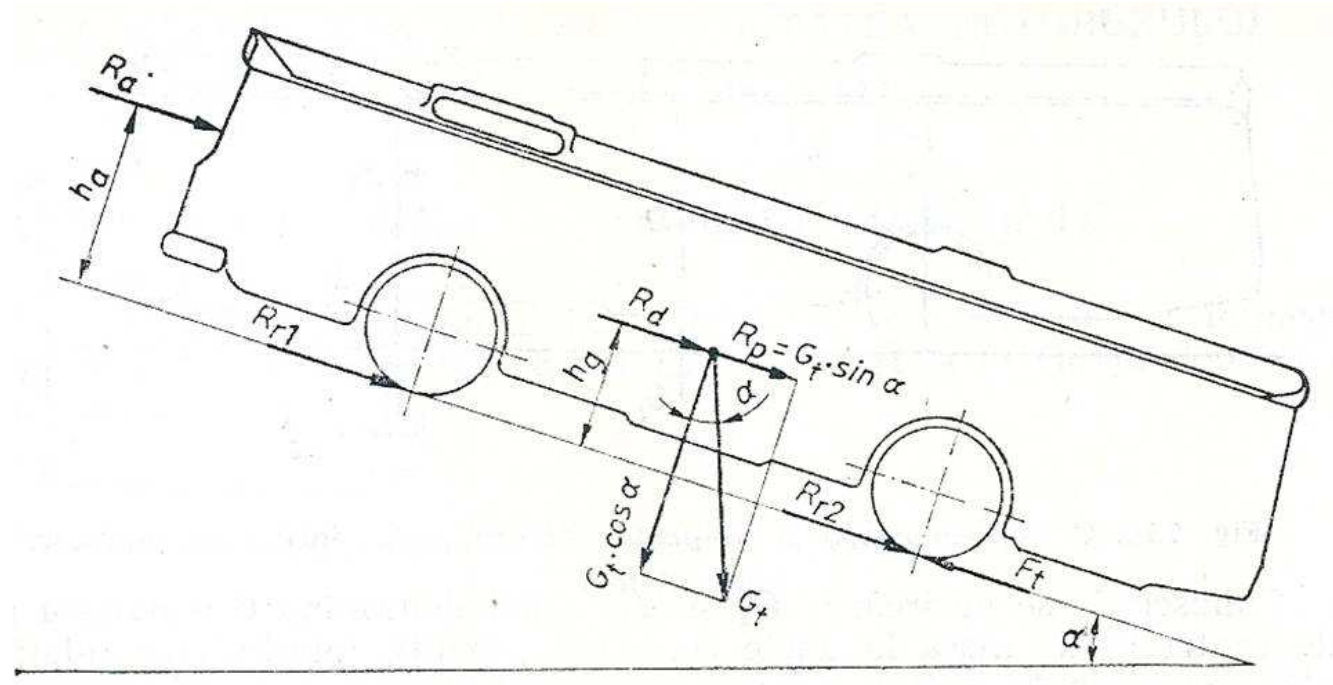

Fig. 6: Forces and reactions acting on a bus that is in a straight line on a $\alpha$ inclination and transient (acceleration)

From the system (20) we find that dynamic loads on the bridges $Z_{1}$ and $Z_{2}$ depend on the total weight of the bus $G_{t}$, the position of the center of gravity $(a, b, h g)$, the slope angle $\alpha$ and the force traction $F_{t}$ and the tractive force loads the rear axle and simultaneously unloads the front axle, the more it is.

Air resistance and acceleration resistance do not really influence the dynamic loads on the two front axles.

\section{Equation of Bus Movement}

In order to establish the general equation of bus movement, it is considered a straight-ahead bus on a $\alpha$ inclination path, in dynamic mode (variable speed, acceleration period).
Figure 6 shows the forces and responses acting on the bus in the mentioned case, these being: The weight of the $G_{t}$ bus (with the two components), the rolling resistance $R_{r 1}$ and $R_{r 2}$ at the two decks, the normal reactions of the path $Z_{1}$ and $Z_{2}$, the resistance due the slope $\mathrm{R}_{\mathrm{p}}$, the air resistance $\mathrm{Ra}$, the acceleration resistance $\mathrm{R}_{\mathrm{d}}$ and the tangential reaction $F_{t}$ of the path to the drive wheels (equal to the traction force).

The projection equation, on a path parallel to the path, of the forces acting on the bus has the form (21) or (22), wherein $R_{r}=R_{r 1}+R_{r 2}$ :

$$
F_{t}-\left(R_{r 1}+R_{r 2}+R_{p}+R_{a}\right)-R_{d}=0
$$




$$
R_{d}=F_{t}-\left(R_{r}+R_{p}+R_{a}\right)
$$

If the acceleration resistance (22) is replaced in relation (22), the expression (23) is obtained, where $\Sigma R^{\prime}$ $=R_{r}+R_{p}+R_{a}$ :

$$
a \cdot \delta \cdot \frac{G_{t}}{g}=F_{t}-\sum R^{\prime}
$$

From the relation (23) directly follows the expression (24), which represents the differential equation of the rectilin motion of the bus; it expresses the value of the acceleration that the bus can obtain for a certain value of the traction force Ft and a certain value of the cumulative resistances $\Sigma R^{\prime}$ :

$$
a=\frac{g}{\delta \cdot G_{t}} \cdot\left(F_{t}-\sum R^{\prime}\right)
$$

\section{Conclusion}

The present paper aims to present the study of the dynamics of the vehicles, with particularization on the buses. Here are the main elements of the bus dynamics, taking into account all the elements that influence the dynamic operation of a bus, in general and in particular situations, with emphasis on the main systems and elements that act on the actual, dynamic, on a normal path or on an inclined with an alpha angle path. The paper presents the second part of the bus dynamics.

\section{Acknowledgement}

This text was acknowledged and appreciated by Dr. Veturia CHIROIU Honorific member of Technical Sciences Academy of Romania (ASTR) PhD supervisor in Mechanical Engineering.

\section{Author's Contributions}

All the authors contributed equally to prepare, develop and carry out this manuscript.

\section{Ethics}

This article is original and contains unpublished material. Authors declare that are not ethical issues and no conflict of interest that may arise after the publication of this manuscript.

\section{References}

Antonescu, P., 2000. Mechanisms and Handlers. 1st Edn., Printech Publishing House, Bucharest.
Antonescu, P. and F. Petrescu, 1985. Analytical method of synthesis of cam mechanism and flat stick. Proceedings of the 4th International Symposium on Mechanism Theory and Practice, (TPM' 85), Bucharest.

Antonescu, P. and F. Petrescu, 1989. Contributions to cinetoelastodynamic analysis of distribution mechanisms. Bucharest.

Antonescu, P., M. Oprean and F. Petrescu, 1985a. Contributions to the synthesis of oscillating cam mechanism and oscillating flat stick. Proceedings of the 4th International Symposium on Theory and Practice of Mechanisms, (TPM' 85), Bucharest.

Antonescu, P., M. Oprean and F. Petrescu, 1985b. At the projection of the oscillante cams, there are mechanisms and distribution variables. Proceedings of the V-Conference for Engines, Automobiles, Tractors and Agricultural Machines, I-Engines and Automobiles, (AMA' 85), Brasov.

Antonescu, P., M. Oprean and F. Petrescu, 1986. Projection of the profile of the rotating camshaft acting on the oscillating plate with disengagement. Proceedings of the 3rd National Computer Assisted Designing Symposium in Mechanisms and Machine Bodies, (MOM' 86), Brasov.

Antonescu, P., M. Oprean and F. Petrescu, 1987. Dynamic analysis of the cam distribution mechanisms. Proceedings of the Seventh National Symposium of Industrial Robots and Spatial Mechanisms, (IMS' 87), Bucharest,

Antonescu, P., M. Oprean and F. Petrescu, 1988. Analytical synthesis of Kurz profile, rotating flat cam cam. Machine Build. Rev. Bucharest.

Antonescu, P., F. Petrescu and O. Antonescu, 1994. Contributions to the synthesis of the rotating cam mechanism and the tip of the balancing tip. Brasov.

Antonescu, P., F. Petrescu and D. Antonescu, 1997. Geometrical synthesis of the rotary cam and balance tappet mechanism. Bucharest.

Antonescu, P., F. Petrescu and O. Antonescu, 2000a. Contributions to the synthesis of the rotary disc-cam profile. Proceedings of the 8th International Conference on Theory of Machines and Mechanisms, (TMM' 00), Liberec, Czech Republic, pp: 51-56.

Antonescu, P., F. Petrescu and O. Antonescu, $2000 \mathrm{~b}$. Synthesis of the rotary cam profile with balance follower. Proceedings of the 8th Symposium on Mechanisms and Mechanical Transmissions (MMT’000), Timişoara, pp: 39-44.

Antonescu, P., F. Petrescu and O. Antonescu, 2001. Contributions to the synthesis of mechanisms with rotary disc-cam. Proceedings of the 8th IFToMM International Symposium on Theory of Machines and Mechanisms, (TMM' 01), Bucharest, ROMANIA, pp: 31-36. 
Aversa, R., R.V. Petrescu, A. Apicella and F.I.T. Petrescu, 2017a. Nano-diamond hybrid materials for structural biomedical application. Am. J. Biochem. Biotechnol., 13: 34-41.

DOI: 10.3844/ajbbsp.2017.34.41

Aversa, R., R.V. Petrescu, B. Akash, R.B. Bucinell and J.M. Corchado et al., 2017b. Kinematics and forces to a new model forging manipulator. Am. J. Applied Sci., 14: 60-80. DOI: 10.3844/ajassp.2017.60.80

Aversa, R., R.V. Petrescu, A. Apicella, F.I.T. Petrescu and J.K. Calautit et al., 2017c. Something about the $\mathrm{V}$ engines design. Am. J. Applied Sci., 14: 34-52. DOI: 10.3844/ajassp.2017.34.52

Aversa, R., D. Parcesepe, R.V. Petrescu, F. Berto and G. Chen et al., 2017d. Processability of bulk metallic glasses. Am. J. Applied Sci., 14: 294-301. DOI: 10.3844/ajassp.2017.294.301

Aversa, R., R.V. Petrescu, A. Apicella and F.I.T. Petrescu, 2017e. Modern transportation and photovoltaic energy for urban ecotourism. Transylvanian Rev. Admin. Sci., 13: 5-20. DOI: $10.24193 /$ tras.SI2017.1

Aversa, R., F.I.T. Petrescu, R.V. Petrescu and A. Apicella, 2016a. Biomimetic FEA bone modeling for customized hybrid biological prostheses development. Am. J. Applied Sci., 13: 1060-1067. DOI: 10.3844/ajassp.2016.1060.1067

Aversa, R., D. Parcesepe, R.V. Petrescu, G. Chen and F.I.T. Petrescu et al., 2016b. Glassy amorphous metal injection molded induced morphological defects. Am. J. Applied Sci., 13: 1476-1482.

DOI: $10.3844 /$ ajassp.2016.1476.1482

Aversa, R., R.V. Petrescu, F.I.T. Petrescu and A. Apicella, 2016c. Smart-factory: Optimization and process control of composite centrifuged pipes. Am. J. Applied Sci., 13: 1330-1341.

DOI: 10.3844 /ajassp.2016.1330.1341

Aversa, R., F. Tamburrino, R.V. Petrescu, F.I.T. Petrescu and M. Artur et al., 2016d. Biomechanically inspired shape memory effect machines driven by muscle like acting NiTi alloys. Am. J. Applied Sci., 13: 1264-1271.

DOI: 10.3844/ajassp.2016.1264.1271

Berto, F., R.V.V. Petrescu and F.I.T. Petrescu, 2016a. A review of recent results on $3 \mathrm{D}$ effects. Am. J. Eng. Applied Sci., 9: 1247-1260.

DOI: 10.3844/ajeassp.2016.1247.1260

Berto, F., R.V.V. Petrescu and F.I.T. Petrescu, $2016 \mathrm{~b}$. Three-dimensional in bonded joints: A short review. Am. J. Eng. Applied Sci., 9: 1261-1268. DOI: 10.3844/ajeassp.2016.1261.1268

Berto, F., A. Gagani, R.V.V. Petrescu and F.I.T. Petrescu, 2016c. Key-hole notches in isostatic graphite: A review of some recent data. Am. J. Eng. Applied Sci., 9: 1292-1300.

DOI: 10.3844/ajeassp.2016.1292.1300
Berto, F., A. Gagani, R. Aversa, R.V.V. Petrescu and A. Apicella et al., 2016d. Multiaxial fatigue strength to notched specimens made of 40CrMoV13.9. Am. J. Eng. Applied Sci., 9: 1269-1291.

DOI: 10.3844/ajeassp.2016.1269.1291

Cao, W., H. Ding, Z. Bin and C. Ziming, 2013. New structural representation and digital-analysis platform for symmetrical parallel mechanisms. Int. J. Adv. Robot. Sys. DOI: 10.5772/56380

Comănescu, A., D. Comănescu, I. Dugăeşescu and A. Boureci, 2010. The Basics of Modeling Mechanisms. 1st Edn., Politehnica Press Publishing House, Bucharest, ISBN-10: 978-606-515-115-4, pp: 274.

Dong, H., N. Giakoumidis, N. Figueroa and N. Mavridis, 2013. Approaching behaviour monitor and vibration indication in developing a General Moving Object Alarm System (GMOAS). Int. J. Adv. Robot. Sys. DOI: $10.5772 / 56586$

De Melo, L.F., R.A., S.F. Rosário and J.M., Rosário, 2012. Mobile robot navigation modelling, control and applications. Int. Rev. Modell. Simulations, 5: 1059-1068.

Frăţilă, G., M. Frăţilă and S. Samoilă, 2011. Automobiles, Construction, Exploitation, Reparation. 10th Edn., EDP, Bucharest, ISBN-13: 978-973-30-2857-4.

Garcia, E., M.A. Jimenez, P.G. De Santos and M. Armada, 2007. The evolution of robotics research. IEEE Robot. Autom. Magaz., 14: 90-103. DOI: 10.1109/MRA.2007.339608

Garcia-Murillo, M., J. Gallardo-Alvarado and E. Castillo-Castaneda, 2013. Finding the generalized forces of a series-parallel manipulator. IJARS. DOI: $10.5772 / 53824$

He, B., Z. Wang, Q. Li, H. Xie and R. Shen, 2013. An analytic method for the kinematics and dynamics of a multiple-backbone continuum robot. IJARS. DOI: $10.5772 / 54051$

Lee, B.J., 2013. Geometrical derivation of differential kinematics to calibrate model parameters of flexible manipulator. Int. J. Adv. Robot. Sys. DOI: $10.5772 / 55592$

Lin, W., B. Li, X. Yang and D. Zhang, 2013. Modelling and control of inverse dynamics for a 5-DOF parallel kinematic polishing machine. Int. J. Adv. Robot. Sys. DOI: 10.5772/54966

Liu, H., W. Zhou, X. Lai and S. Zhu, 2013. An efficient inverse kinematic algorithm for a PUMA560structured robot manipulator. IJARS. DOI: $10.5772 / 56403$

Mirsayar, M.M., V.A. Joneidi, R.V. Petrescu, F.I.T. Petrescu and F. Berto, 2017. Extended MTSN criterion for fracture analysis of soda lime glass. Eng. Fracture Mechan., 178: 50-59. DOI: 10.1016/j.engfracmech.2017.04.018 
Padula, F. and V. Perdereau, 2013. An on-line path planner for industrial manipulators. Int. J. Adv. Robot. Sys. DOI: 10.5772/55063

Pelecudi, C., 1967. The Basics of Mechanism Analysis. Publishing house: Academy of the People's Republic of Romania.

Perumaal, S. and N. Jawahar, 2013. Automated trajectory planner of industrial robot for pick-andplace task. IJARS. DOI: 10.5772/53940

Petrescu, F. and R. Petrescu, 1995a. Contributions to optimization of the polynomial motion laws of the stick from the internal combustion engine distribution mechanism. Bucharest.

Petrescu, F. and R. Petrescu, 1995b. Contributions to the synthesis of internal combustion engine distribution mechanisms. Bucharest.

Petrescu, F. and R. Petrescu, 1997a. Dynamics of cam mechanisms (exemplified on the classic distribution mechanism). Bucharest.

Petrescu, F. and R. Petrescu, 1997b. Contributions to the synthesis of the distribution mechanisms of internal combustion engines with Cartesian coordinate method. Bucharest.

Petrescu, F. and R. Petrescu, 1997c. Contributions to maximizing polynomial laws for the active stroke of the distribution mechanism from internal combustion engines. Bucharest.

Petrescu, F. and R. Petrescu, 2000a. Synthesis of distribution mechanisms by the rectangular (cartesian) coordinate method. University of Craiova, Craiova.

Petrescu, F. and R. Petrescu, 2000b. The design (synthesis) of cams using the polar coordinate method (the triangle method). University of Craiova, Craiova.

Petrescu, F. and R. Petrescu, 2002a. Motion laws for cams. Proceedings of the 7 th National Symposium with International Participation Computer Assisted Design (PAC' 02), Braşov, pp: 321-326.

Petrescu, F. and R. Petrescu, 2002b. Camshaft dynamics elements. Proceedings of the 7th National Symposium with International Participation Computer Assisted Design (PAC' 02), Braşov, pp: 327-332.

Petrescu, F. and R. Petrescu, 2003. Some elements regarding the improvement of the engine design. Proceedings of the 8th National Symposium, Descriptive Geometry, Technical Graphics and Design, (GTD’03), Braşov, pp: 353-358.

Petrescu, F. and R. Petrescu, 2005a. The cam design for a better efficiency. Proceedings of the International Conference on Engineering Graphics and Design, (EGD’ 05), Bucharest, pp: 245-248.

Petrescu, F. and R. Petrescu, 2005b. Contributions at the dynamics of cams. Proceedings of the 9th IFToMM International Symposium on Theory of Machines and Mechanisms, (TMM' 05), Bucharest, Romania, pp: $123-128$.
Petrescu, F. and R. Petrescu, 2005c. Determining the dynamic efficiency of cams. Proceedings of the 9th IFToMM International Symposium on Theory of Machines and Mechanisms, (TMM' 05), Bucharest, Romania, pp: 129-134.

Petrescu, F. and R. Petrescu, 2005d. An original internal combustion engine. Proceedings of the 9th IFToMM International Symposium on Theory of Machines and Mechanisms, (TMM' 05), Bucharest, Romania, pp: 135-140.

Petrescu, F. and R. Petrescu, 2005e. Determining the mechanical efficiency of Otto engine's mechanism. Proceedings of the 9th IFToMM International Symposium on Theory of Machines and Mechanisms, (TMM' 05), Bucharest, Romania, pp: 141-146.

Petrescu, F.I. and R.V. Petrescu, 2013. Cinematics of the 3R Dyad. Engevista, 15: 118-124.

Petrescu, F.I. and R.V. Petrescu, 2012a. Kinematics of the planar quadrilateral mechanism. Engevista, 14: 345-348.

Petrescu, F.I. and R.V. Petrescu, 2012b. MecatronicaSisteme Seriale si Paralele. Create Space Publisher, USA, ISBN-10: 978-1-4750-6613-5, pp: 128.

Petrescu, F.I. and R.V. Petrescu, 2011. Mechanical Systems, Serial and Parallel-Course (in Romanian). LULU Publisher, London, UK, ISBN-10: 978-1-4466-0039-9, pp: 124.

Petrescu, F.I. and R.V. Petrescu, 2016a. Parallel moving mechanical systems kinematics, ENGEVISTA, 18: 455-491.

Petrescu, F.I. and R.V. Petrescu, 2016b. Direct and inverse kinematics to the Anthropomorphic Robots, ENGEVISTA, 18: 109-124.

Petrescu, F. and R. Petrescu, 2016c. An otto engine dynamic model. IJM\&P, 7: 038-048.

Petrescu, F.I. and R.V. Petrescu, 2016d. Otto motor dynamics, GEINTEC, 6: 3392-3406.

Petrescu, F.I. and R.V. Petrescu, 2016e. Dynamic cinematic to a structure 2R. GEINTEC, 6: 3143-3154.

Petrescu, F.I., B. Grecu, A. Comanescu and R.V. Petrescu, 2009. Some mechanical design elements. Proceeding of the International Conference on Computational Mechanics and Virtual Engineering, (MEC' 09), Braşov, pp: 520-525.

Petrescu, R.V., R. Aversa, A. Apicella, M.M. Mirsayar and F.I.T. Petrescu, 2016a About the gear efficiency to a simple planetary train. Am. J. Applied Sci., 13: 1428-1436.

Petrescu, R.V., R. Aversa, A. Apicella, S. Li and G. Chen et al., 2016b. Something about electron dimension. Am. J. Applied Sci., 13: 1272-1276.

Petrescu, F.I.T., A. Apicella, R. Aversa, R.V. Petrescu and J.K. Calautit et al., 2016c. Something about the mechanical moment of inertia. Am. J. Applied Sci., 13: $1085-1090$. 
Petrescu, R.V., R. Aversa, A. Apicella, F. Berto and S. Li et al., 2016d. Ecosphere protection through green energy. Am. J. Applied Sci., 13: 1027-1032.

Petrescu, F.I.T., A. Apicella, R.V. Petrescu, S.P. Kozaitis and R.B. Bucinell et al., 2016e. Environmental protection through nuclear energy. Am. J. Applied Sci., 13: 941-946.

Petrescu, F.I.T. and J.K. Calautit, 2016a. About nano fusion and dynamic fusion. Am. J. Applied Sci., 13: 261-266.

Petrescu, F.I.T. and J.K. Calautit, 2016b. About the light dimensions. Am. J. Applied Sci., 13: 321-325.

Petrescu, R.V., R. Aversa, B. Akash, R. Bucinell and J. Corchado et al., 2017a. Modern propulsions for aerospace-a review. J. Aircraft Spacecraft Technol., 1: 1-8. DOI: $10.3844 /$ jastsp.2017.1.8

Petrescu, R.V., R. Aversa, B. Akash, R. Bucinell and J. Corchado et al., 2017b. Modern propulsions for aerospace-part II. J. Aircraft Spacecraft Technol., 1: 9-17. DOI: 10.3844/jastsp.2017.9.17

Petrescu, R.V., R. Aversa, B. Akash, R. Bucinell and J. Corchado et al., 2017c. History of aviation-a short review. J. Aircraft Spacecraft Technol., 1: 30-49. DOI: 10.3844 /jastsp.2017.30.49

Petrescu, R.V., R. Aversa, B. Akash, R. Bucinell and J. Corchado et al., 2017d. Lockheed martin-a short review. J. Aircraft Spacecraft Technol., 1: 50-68. DOI: 10.3844 jastsp.2017.50.68

Petrescu, R.V., R. Aversa, B. Akash, J. Corchado and F. Berto et al., 2017e. Our universe. J. Aircraft Spacecraft Technol., 1: 69-79. DOI: 10.3844 jastsp.2017.69.79

Petrescu, R.V., R. Aversa, B. Akash, J. Corchado and F. Berto et al., 2017f. What is a UFO? J. Aircraft Spacecraft Technol., 1: 80-90.

DOI: 10.3844 jastsp.2017.80.90

Petrescu, R.V., R. Aversa, B. Akash, J. Corchado and F. Berto et al., 2017g. About bell helicopter FCX-001 concept aircraft-a short review. J. Aircraft Spacecraft Technol., 1: 91-96.

DOI: 10.3844 /jastsp.2017.91.96

Petrescu, R.V., R. Aversa, B. Akash, J. Corchado and F. Berto et al., 2017h. Home at airbus. J. Aircraft Spacecraft Technol., 1: 97-118. DOI: $10.3844 /$ jastsp.2017.97.118

Petrescu, R.V., R. Aversa, B. Akash, J. Corchado and F. Berto et al., 2017i. Airlander. J. Aircraft Spacecraft Technol., 1: 119-148. DOI: 10.3844 /jastsp.2017.119.148

Petrescu, R.V., R. Aversa, B. Akash, J. Corchado and F. Berto et al., 2017j. When boeing is dreaming-a review. J. Aircraft Spacecraft Technol., 1: 149-161. DOI: $10.3844 /$ jastsp.2017.149.161
Petrescu, R.V., R. Aversa, B. Akash, J. Corchado and F. Berto et al., 2017k. About Northrop Grumman. J. Aircraft Spacecraft Technol., 1: 162-185. DOI: 10.3844/jastsp.2017.162.185

Petrescu, R.V., R. Aversa, B. Akash, J. Corchado and F. Berto et al., 20171. Some special aircraft. J. Aircraft Spacecraft Technol., 1: 186-203. DOI: 10.3844/jastsp.2017.186.203

Petrescu, R.V., R. Aversa, B. Akash, J. Corchado and F. Berto et al., 2017m. About helicopters. J. Aircraft Spacecraft Technol., 1: 204-223. DOI: 10.3844/jastsp.2017.204.223

Petrescu, R.V., R. Aversa, B. Akash, F. Berto and A. Apicella et al., 2017n. The modern flight. J. Aircraft Spacecraft Technol., 1: 224-233. DOI: 10.3844 /jastsp.2017.224.233

Petrescu, R.V., R. Aversa, B. Akash, F. Berto and A. Apicella et al., 2017o. Sustainable energy for aerospace vessels. J. Aircraft Spacecraft Technol., 1: 234-240. DOI: 10.3844/jastsp.2017.234.240

Petrescu, R.V., R. Aversa, B. Akash, F. Berto and A. Apicella et al., 2017p. Unmanned helicopters. J. Aircraft Spacecraft Technol., 1: 241-248. DOI: $10.3844 /$ jastsp.2017.241.248

Petrescu, R.V., R. Aversa, B. Akash, F. Berto and A. Apicella et al., 2017q. Project HARP. J. Aircraft Spacecraft Technol., 1: 249-257. DOI: $10.3844 /$ jastsp.2017.249.257

Petrescu, R.V., R. Aversa, B. Akash, F. Berto and A. Apicella et al., 2017r. Presentation of romanian engineers who contributed to the development of global aeronautics-part I. J. Aircraft Spacecraft Technol., 1: 258-271. DOI: $10.3844 /$ jastsp.2017.258.271

Petrescu, R.V., R. Aversa, B. Akash, F. Berto and A. Apicella et al., 2017s. A first-class ticket to the planet mars, please. J. Aircraft Spacecraft Technol., 1: 272-281. DOI: 10.3844/jastsp.2017.272.281

Petrescu, R.V., R. Aversa, B. Akash, F. Berto and A. Apicella et al., 2017t. Forces of a 3R robot. J. Mechatronics Robotics, 1: 1-14. DOI: $10.3844 /$ jmrsp.2017.1.14

Petrescu, R.V., R. Aversa, B. Akash, F. Berto and A. Apicella et al., 2017u. Direct geometry and cinematic to the MP-3R systems. J. Mechatronics Robotics, 1: 15-23. DOI: 10.3844/jmrsp.2017.15.23

Petrescu, R.V., R. Aversa, B. Akash, F. Berto and A. Apicella et al., 2017v. Dynamic elements at MP3R. J. Mechatronics Robotics, 1: 24-37. DOI: $10.3844 /$ jmrsp.2017.24.37

Petrescu, R.V., R. Aversa, B. Akash, F. Berto and A. Apicella et al., 2017w. Geometry and direct kinematics to MP3R with $4 \times 4$ operators. J. Mechatronics Robotics, 1: 38-46. DOI: $10.3844 / j \mathrm{mrsp} .2017 .38 .46$ 
Petrescu, R.V., R. Aversa, A. Apicella, M.M. Mirsayar and S. Kozaitis et al., 2017x. Current stage in the field of mechanisms with gears and rods. J. Mechatronics Robotics, 1: 47-57.

DOI: $10.3844 /$ jmrsp.2017.47.57

Petrescu, R.V., R. Aversa, A. Apicella, M.M. Mirsayar and S. Kozaitis et al., 2017y. Geometry and inverse kinematic at the MP3R mobile systems. J. Mechatronics Robotics, 1: 58-65. DOI: $10.3844 / \mathrm{jmrsp} .2017 .58 .65$

Petrescu, R.V., R. Aversa, A. Apicella, M.M. Mirsayar and S. Kozaitis et al., 2017z. Synthesis of optimal trajectories with functions control at the level of the kinematic drive couplings. J. Mechatronics Robotics, 1: 66-74. DOI: 10.3844/jmrsp.2017.66.74

Petrescu, R.V., R. Aversa, A. Apicella, M.M. Mirsayar and S. Kozaitis et al., 2017aa. The inverse kinematics of the plane system 2-3 in a mechatronic MP2R system, by a trigonometric method. J. Mechatronics Robotics, 1: 75-87. DOI: 10.3844 /jmrsp.2017.75.87

Petrescu, R.V., R. Aversa, A. Apicella, M.M. Mirsayar and S. Kozaitis et al., 2017ab. Serial, anthropomorphic, spatial, mechatronic systems can be studied more simply in a plan. J. Mechatronics Robotics, 1: 88-97. DOI: 10.3844/jmrsp.2017.88.97

Petrescu, R.V., R. Aversa, A. Apicella, M.M. Mirsayar and S. Kozaitis et al., 2017ac. Analysis and synthesis of mechanisms with bars and gears used in robots and manipulators. J. Mechatronics Robotics, 1: 98-108.

DOI: $10.3844 /$ jmrsp.2017.98.108
Petrescu, R.V., R. Aversa, A. Apicella, M.M. Mirsayar and S. Kozaitis et al., 2017ad. Speeds and accelerations in direct kinematics to the MP3R systems. J. Mechatronics Robotics, 1: 109-117. DOI: $10.3844 /$ jmrsp.2017.109.117

Petrescu, R.V., R. Aversa, A. Apicella, M.M. Mirsayar and S. Kozaitis et al., 2017ae. Geometry and determining the positions of a plan transporter manipulator. J. Mechatronics Robotics, 1: 118-126. DOI: $10.3844 /$ jmrsp.2017.118.126

Reddy, P., K.V. Shihabudheen and J. Jacob, 2012. Precise non linear modeling of flexible link flexible joint manipulator. IReMoS, 5: 1368-1374.

Tabaković, S., M. Zeljković, R. Gatalo and A. Živković, 2013. Program suite for conceptual designing of parallel mechanism-based robots and machine tools. Int. J. Adv. Robot Syst. DOI: $10.5772 / 56633$

Tang, X., D. Sun and Z. Shao, 2013. The structure and dimensional design of a reconfigurable PKM. IJARS. DOI: $10.5772 / 54696$

Tong, G., J. Gu and W. Xie, 2013. Virtual entity-based rapid prototype for design and simulation of humanoid robots. Int. J. Adv. Robot. Sys. DOI: $10.5772 / 55936$

Wang, K., M. Luo, T. Mei, J. Zhao and Y. Cao, 2013. Dynamics analysis of a three-DOF planar serialparallel mechanism for active dynamic balancing with respect to a given trajectory. Int. J. Adv. Robotic Sys. DOI: 10.5772/54201

Wen, S., J. Zhu, X. Li, A. Rad and X. Chen, 2012. Endpoint contact force control with quantitative feedback theory for mobile robots. IJARS. DOI: $10.5772 / 53742$ 